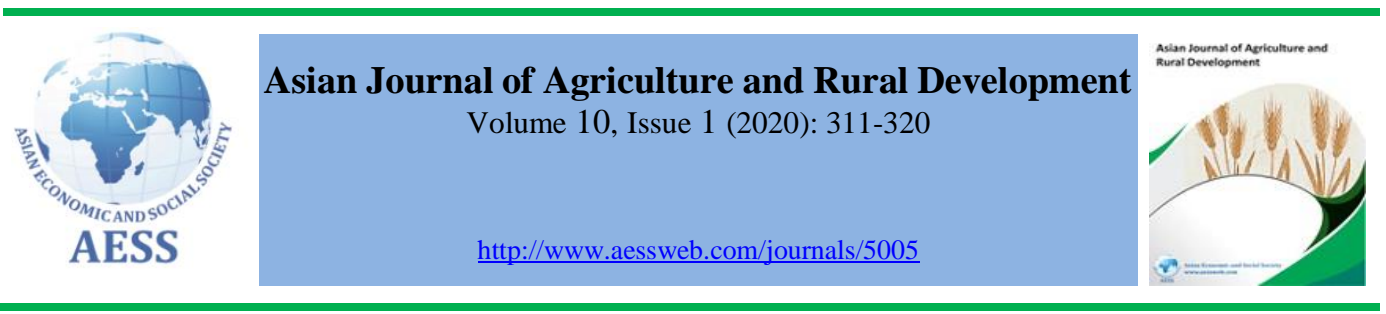

\title{
PURCHASING POWER OF FARMERS - CHALLENGES AND OPPORTUNITIES IN INDIAN AGRICULTURE
}

Vanishree

Pabalkar ,

Rashmy Morey,

Shivanand Rai

\section{ARTICLE HISTORY:}

Received: $20-$-Oct-2019

Accepted: 28-Apr-2020

Online Available: 30-May2020

\section{Keywords:}

Agriculture,

Farmers,

Employment,

Sustainable,

Purchasing power
Symbiosis International (Deemed University), India

- vanishree.p@sims.edu (Corresponding author)

ABSTRACT
The objective of the study is to analyse the farmer's financial
condition and to understand the challenges faced in exhibiting the
power of purchasing. The study indicates that there is abundant scope
to improve the agriculture and financial condition of farmers in the
entire country. The primary input for the study has been collected by
an informal interview with focus groups of various populations of
farmers, retailers, distributors, opinion leaders, and government
officials to find out the status of agriculture and financial conditions of
farmers. The total sample size was 500 farmers for empirical analysis.

\section{ABSTRACT} condition and to understand the challenges faced in exhibiting the power of purchasing. The study indicates that there is abundant scope to improve the agriculture and financial condition of farmers in the entire country. The primary input for the study has been collected by an informal interview with focus groups of various populations of officials to find out the status of agriculture and financial conditions of farmers. The total sample size was 500 farmers for empirical analysis.

\section{Contribution/ Originality}

The research paper captures the status of the agricultural scenario in India. The different mechanisms through which the Yield of the farmer can be marketed is addressed in this study. The various schemes like the Vishesh Krishi and Gram Udyog are not much discussed in the other research papers, which came out as the gap in the literature review.

DOI: 10.18488/journal.1005/2020.10.1/1005.1.311.320

ISSN (P): 2304-1455/ISSN (E):2224-4433

How to cite: Vanishree Pabalkar, Rashmy Morey, and Shivanand Rai (2020). Purchasing power of farmers - Challenges and opportunities in Indian Agriculture. Asian Journal of Agriculture and Rural Development, 10(1), 311-320.

(C) 2020 Asian Economic and Social Society. All rights reserved. 


\section{INTRODUCTION}

Agriculture has always been recognized as a vital vocation with cultural traditions, social customs, and even religious rites associated with agricultural practices. In India, Agriculture amounts to approximately 15 percent of the GDP. This is one of the largest sectors employing people. As per the official records, the total no. of farmers in the rural areas amounts to only a few hundred million, there are the family members of these farmers who support them in the activities and are the wage laborers. With this, the total goes to nearly half a billion people. Since the 1990s, there have been implications of weather that put farmers into the state of financial losses. In 2006, India had to import wheat for the first time. The agriculture system in India comprises of a blend of conventional and advanced techniques together. The conventional system contributes to the lower side of per capita income from the farmer.

This research pertains to the analysis of the rural economy of India. The $59^{\text {th }}$ survey by the National Sample Survey office stating that about 40 percent of farmers did not get appealed by farming and would quit given a chance. Farm business income has been dropping since the late 1990s. Further, farmers' suicides in Uttar Pradesh (UP) a province of India, previously limited to the Bundelkhand region, are being reported from all parts of the state, including the relatively prosperous region of western UP. There were 12,602 suicide cases in the year 2015, out of which 8007 were farmers and 4595 were laborers who assist the farmers. The key reasons for suicide include bankruptcy or debts. Indebtedness is one of the major causes of suicides (Talule, 2013). Approximately 12 percent of farmers have family problems and 10.5 percent have health problems. In the year $2015,45.2 \%$ of small farmers and $27.4 \%$ of marginal farmers had committed suicide. The financial crisis is a fundamental cause of farmers' suicide. The condition has proved to be the same for many years. There was no significant change in the financial aspects of Indian farmers. The traders on one hand and the financiers on the other are the main reasons for suicides in Maharashtra (Manjunath and Ramappa, 2017).

The agriculture sector compared to other sectors is not significantly profitable. The purchasing power of the farmers has been reducing. The social schemes which include midday meals for school kids and other schemes on rural health insurance along with Mahatma Gandhi National Rural Employment Guarantee Scheme etc, have been in existence, yet do not contribute to a great extent in enhancing the purchasing power of the farmers (Dhas, 2009). There is abundant stress on the farmers (Sangalad, 2012). As per Chandrasekhar and Ghosh (2004), notable reasons for farmers to live below the poverty line were increased costs of fertilizers, supply chain problems, reduction in bank credit, and inappropriate marketing facilities, etc. (Shakeel-Ul-Rehman et al., 2012). The Government of India has committed to offering the farmers with a minimum support price and 50 percent profit. Unfortunately, this failed drastically. The failure of crops leads to farmer's migration of farmers from rural to urban areas. This further leads to the dip in the realty prices of agricultural land. It was found that the suicide rates went up from 1995 to 2011, the reasons being drought conditions. The Government did not cater to spend much to meet the requirements during such conditions (Parida et al., 2018). Peasant politics is just not capable of making things better, as most of the peasant agitations that happened in the past decade or more have revolved around the issue of land acquisition. Their target has been to get a better deal from the state through higher prices.

The State is expected to set an example in terms of ethical practices and standards. Unlike the private sector, governments can define and control the rules that guide public purchases, making it both a player and a decision-maker in markets. Importantly, the large size of government purchases gives public procurement the power to influence markets and regulate market players. Given its power, public procurement has been used to serve several development goals, including job creation, innovation, industrial growth, environmental sustainability, and social inclusion (McCrudden, 2007; Arrowsmith, 2010). Public procurement processes are in principle designed to 
enable governments to purchase goods and services as cost-effectively as possible. However, procuring entities normally consider aspects other than cost-efficiency when purchasing goods and services (Arrowsmith, 2010). For example, governments in all cases require compliance with legal norms and obligations, such as paying taxes and complying with labor law and health and safety regulations. This is designed to ensure that public procurement is not associated with unlawful behavior.

Procurement policies can also be instrumental in enabling the State to advance social, economic, political, and environmental benefits that go beyond compliance with general law and responding to the public sector's procurement need. Socio-economic and environmental concerns can, for example, inform governments' decisions on which goods and services to purchase. Procuring entities may, for instance, decide to only procure fairly traded goods or invest in green products (UNEP, 2013).

The World Food Programme (2013) estimates that governments spend between USD47 billion and USD75 billion a year globally on school meals. Linking public food procurement to domestic food production can be used to promote economic outcomes in a similar vein to the benefits generated by public procurement on SME development. Expanding marketing opportunities for producers and rural enterprises can boost rural economies and communities by promoting growth and job creation in the food sector. This link has been promoted by several countries in all parts of the world, for example, the USA, the UK, Italy, Brazil, and Thailand (USDA, 2015; Morgan and Sonnino, 2008).

In many developing countries, public food procurement has specifically targeted smallholder farmers to promote their economic inclusion and strengthen local food systems. In this case, the rationale is that public food procurement can reduce some of the uncertainties and risks related to market participation by providing an accessible market channel and a source of income to farmers. Greater market participation and an additional source of income can generate several positive impacts such as increases in household food consumption, dietary diversity, and higher Investments underway and enhancement (Sumberg and Sabates-Wheeler, 2011). Also, enhancements to smallholder occupations can create positive overflow impacts in nearby economies. Moreover, open nourishment obtainment can likewise prompt positive results on wellbeing and sustenance, especially among kids and other defenseless gatherings (Niebylski et al., 2014). Nourishment acquisition can target better-quality and all the more healthfully adjusted dinners, improving their dietary status and empowering more advantageous dietary patterns. Research in England, Scotland, Canada, and the USA have demonstrated that nourishment and supplement admission improved after leafy food was acquainted with dinners in schools, emergency clinics, and other open offices (Niebylski et al., 2014; Cohen et al., 2014). Increments in sound nourishment utilization likewise prompted upgrades in wellbeing markers, for example, lower circulatory strain and Body Mass Index (BMI) among recipients. Most investigations on the effects of open nourishment obtainment on wellbeing and sustenance have concentrated on evolved economies. Be that as it may, this connection has likewise been investigated in creating nations, for the most part, according to the class taking care of. In low-salary nations, school nourishment has been generally utilized as a social assurance methodology (Bundy, 2008). Open nourishment obtainment can address the wholesome prerequisites of younger students by expanding the gracefully of nutritious food sources. Some pilot encounters in Malawi, Mozambique, and Ethiopia have been effective at utilizing nourishment obtainment techniques to present privately sourced organic products, vegetables, and heartbeats to class menus, enhancing kids' weight control plans and expanding access to supplement rich food sources (Gyori et al., 2016).

Governments are additionally looking to make collaboration between nourishment acquirement and SPP approaches to encourage progressively maintainable nourishment frameworks. For instance, in the EU, nourishment and providing food is a significant class under the Green Public Procurement 
approach. Open obtainment can support creative strategies that are all the more earth neighborly, for example, natural nourishment. This methodology has been widely embraced in Sweden, Finland, and Denmark (Risku and Loes, 2017; Sørensen et al., 2016; Smith, 2016). The acquirement of regular nourishment International Policy Center for Inclusive Growth 11 and preferring short flexibly chains can likewise build interest for wares and items that have lower ozone-depleting substance emanations. Indeed, buying nourishment from nearby providers/makers is a typical technique to advance increasingly practical open acquisition in a few nations across Europe and Asia just as North and Latin America (Brammer and Walker, 2011).

Though the government is trying to contribute a lot through various schemes to complete the transition of the villages and farming systems, efficient ways of utilizing water, and information provision on weather-based crop insurance. Further, the budget of 2017-18, had initiatives towards sustainable development of agriculture, such as an allocation of US\$ 28.1 billion for rural development, a separate micro-irrigation fund; National Bank for Agriculture and Rural Development (NABARD) was established with a fund of US\$ 750 million. The government intends to introduce a dairy processing fund of US\$ 1.2 billion for the coming years which would have an initial corpus of US\$ 300 million. The inclusion of females in the Mahatma Gandhi National Rural Employment Guarantee Act (MGNREGA) multiplied by 55 percent. The scheme was brought up to US\$ 7.2 billion for FY2017-18. Short-term crop loans were introduced up to US\$ 4,500 for a lower interest rate of 7 percent per annum.

Some of the recent major Indian government initiatives in the sector are as follows:

- A think tank, NITI Aayog was established to achieve sustainable development goals with cooperative federalism by fostering the involvement of State Governments of India in the economic policy-making process using a bottom-up approach. This think tank introduced several reforms including direct purchase from farmers without intermediaries to ensure costsaving.

- The Maharashtra State Agriculture Marketing Board (MSAMB) had introduced 31 farmer-toconsumer markets. This would ensure direct sales of farmers to end consumers thereby leading to better outputs and better monetary benefits to farmers.

- The Ministry of Labor and Employment intends to have the policy of the Minimum Wage Act to be changed to meet the needs of other labors who are not skilled.

- The Central Government intends to provide the farmers with assistance in advancements through technology. The advancements in technology have empowered rural customers to have better access to information and thereby having a greater role in the purchase decisions made by rural customers especially. These rural customers are as much as about close to 70 percent of the population. This is contributing to 50 percent of GDP. The patterns of buying and consuming are now varying with rural customers as well.

- India's per capita GDP coming from the rural market has multiplied at a compound annual growth rate of 6.2 percent since the year 2000. The fast-moving consumer goods (FMCG) sector in rural areas and semi-urban areas is bound to touch US\$ 100 billion by 2025 (www.ibef.org).

Maharashtra state has very diverse agro-climatic conditions that are more appropriate for producing a variety of crops. However, the key contribution of revenue generated from the industrial sectors of the state. The state is a pioneer in water-saving technology as well. Drip and sprinkler irrigation, technology is significant in the state. This amounts to 60 percent of the total area for drip irrigation in the country. More than 70 percent of the area covers the grapes and banana and has access to drip irrigation. It is one of the major exporters of Thompson seedless grapes, Alphonso mangoes, onions, and long stem cut flowers (Kumar, 2016). Declining diversity of crops can have serious repercussions for natural resources, ecology, and socio-economic condition of the farmers (Haroon and Sandip, 2014). Other schemes introduced by the state for the 
benefit of farmers and exporters are included Vishesh Krishi Upaj Yojana, Gram Udyog Yojana, and NABARD.

Farming is one of the sectors that have been given priority by the Government. However, the issues regarding the laborers, regulations, and standardization of procedures are required. Firstly, there is a lack of skilled laborers in the sector, and the available ones are not equipped with the required skill sets to carry out the tasks effectively. There is a need for training of the unskilled laborers to keep up in the sector. Programs to re-skill and develop the farmers for other jobs can be taken up. Going digital is another option, with more emphasis on getting hands-on experience through technology and agricultural skilled efforts. (Status and determinants of small farming households' food security and the role of market access in enhancing food security in rural Pakistan (Ahmed et al., 2017).

\subsection{Major challenges for farmers}

Global warming. The yield produced will subsequently drop because of the moderate warming of around $1-2^{\circ} \mathrm{C}$. The dry areas will be drastically affected and the yield in the pasture areas may improve. Resulting in reduced crop yields in seasonally dry and tropical regions, while crop and pasture yields in temperate regions may benefit. Global warming in the latter part of the century may lead to drastic changes across all the regions of the country.

Extreme climate events. Extreme changes in the climatic conditions in the times ahead may destroy the entire ecosystem of the cycle. The changes could be in the form of floods, natural calamities, droughts, tsunami, etc. This will have a negative impact on agriculture and allied areas (Singh and Issac, 2018).

Undernourishment. The ratio of undernourished would multiply; this is expected to approximately go up to 5170 million people by the year 2080, concerning a baseline with absolutely no change in the weather. The production itself of food will be curtailed thereby increasing the risk of nonavailability of food and increased risk of hunger in the developing and not so rich countries.

Food stability, utilization, and access. The adverse effects of non-availability of food and the issues on climate change on food security are not yet clearly identified statistically. The risk will be the worst, with severe climatic conditions (Easterling et al., 2007).

Illiteracy is one of the major concerns that lead to a lack of awareness of advancement in any field. The poor socio-economic background of the farmers is the major reason for diminishing agricultural productivity. The gap that exists between the high end and low-end farmers and the farmers who have their basic needs unmet, is the conditions for low productivity (Dwivedi, 2011; Division, 2007).

Improper finance, irregular and inconsistent policies, and other policies which are contradicting the policies of the government are all the reasons for an increased level of problems and challenges faced by the farmers (Dwivedi, 2011). Adequate availability of funds at the appropriate time when the farmers need them the most or making credit facilities available to farmers at low-interest rates is a few aspects that should be considered for ensuring greater output.

There exists an abundant high rate of regional disparity for water resources. There is an increasing demand for clean drinking water.

\subsection{Objectives of the study}

The current study aimed to understand the status of Indian agriculture system focusing on the following issues, 
1. Understand the economic status of agriculture in India generally and Maharashtra state particularly.

2. Understand the purchasing power and financial conditions of farmers in rural areas of India.

3. Critically analyze the issues and challenges of farmers.

4. Evaluating the ways of marketing and promoting the farmer's produce.

5. Recommend measures for improving the financial conditions of farmers.

\section{METHODOLOGY}

The primary input has been collected by an informal interview with focus groups of various populations of farmers, retailers, distributors, opinion leaders, government officials to find out the status of agriculture and financial conditions of farmers. The facts and figures have been also searched from various websites and newspapers, and published articles related to the subject of the project.

\subsection{Data collection}

Collecting primary data was a critical phase of this study. Considering all these factors, 'Informal discussion' was the method chosen to collect the primary data. Informal discussions on the topic of demonetization and without asking directly pointed questions, from the respondent of the focus group had taken place. Choosing this method ensured that any 'bias' is removed in the response and that helped me to collect the facts on this very sensitive issue.

The primary data obtained from the districts of Pune and Sholapur from the focus group, with a sample size of approximately 10 to 50 or more. The total sample size was 500 farmers from Pune and Sholapur.

Secondary data was collected from print and digital media as well as from literature for overall Maharashtra state and India.

The total Sholapur district population living in rural areas is 2.918 million and that of the Pune district population living in rural areas is 3.678 making it 6596891 at all.

Solvin's formula for sample size

$\mathrm{n}=\mathrm{N} /\left(1+\mathrm{N} \mathrm{e}^{2}\right)=$ at 95 percent confidence level

$1,000 /\left(1+1000 * 0.05^{2}\right)=285.714286$

$\mathrm{n}=500 /\left(1+500 * 0.05^{2)}=500 /(1+500 * 0.0025)\right.$

$\mathrm{n}=500 /(501 * 0.0025)$

$\mathrm{n}=500 /(1.2525)=399$

The required sample size is 399 . However, a sample size of 500 is chosen for the current study. ( 0.01 percent of the population of rural households)

Feedback from 50 farmers or sellers were taken at a time during distributor's and farmer's conferences from time to time. This included a rural population of villagers and farmers, agriculture input sellers including fertilizers, pesticides, and seed, etc. to understand the following:

1. The sales and consumption of agriculture inputs like fertilizers and seeds.

2. Marketing of agriculture produce, profitability out of crop production, availability of resources for undertaking agriculture production. 


\section{RESULTS}

It was noted that farmers in Maharashtra are quite progressive and knowledgeable, uses drip and spray irrigation of micro-irrigation system, and do balance use of fertilizer $95 \%$ of farmers have not done soil testing and do not know about soil testing facilities. 90 percent of farmers use biofertilizers like compost fertilizers. 90 percent of farmers adopt the prevailing cropping pattern using biofertilizers. Only 15 percent of farmers reported that they used balanced fertilizers. 95 percent of farmers get the fertilizers as per their needs and demand. 65 percent of farmers use the wrong practice of spraying fertilizer under waterlogging conditions. Poor infrastructure facilities are the primary causes of poor output.

It is also observed that farmers are not happy with government policies of importing onions, banning the export of onions, and not providing proper logistics and warehousing for excess production of perishable fruits and vegetables. Though the schemes are in place, crop production does not have any effect on the policies framed by the Government. The figure below being selfexplanatory for the socioeconomic profiles of the farmers. 90 percent of farmers are in the occupation of more than a decade and have this as a primary source of income. Others are newly entered. They are not skilled in any activities beyond farming making it difficult for them to migrate and find other sources of employment.

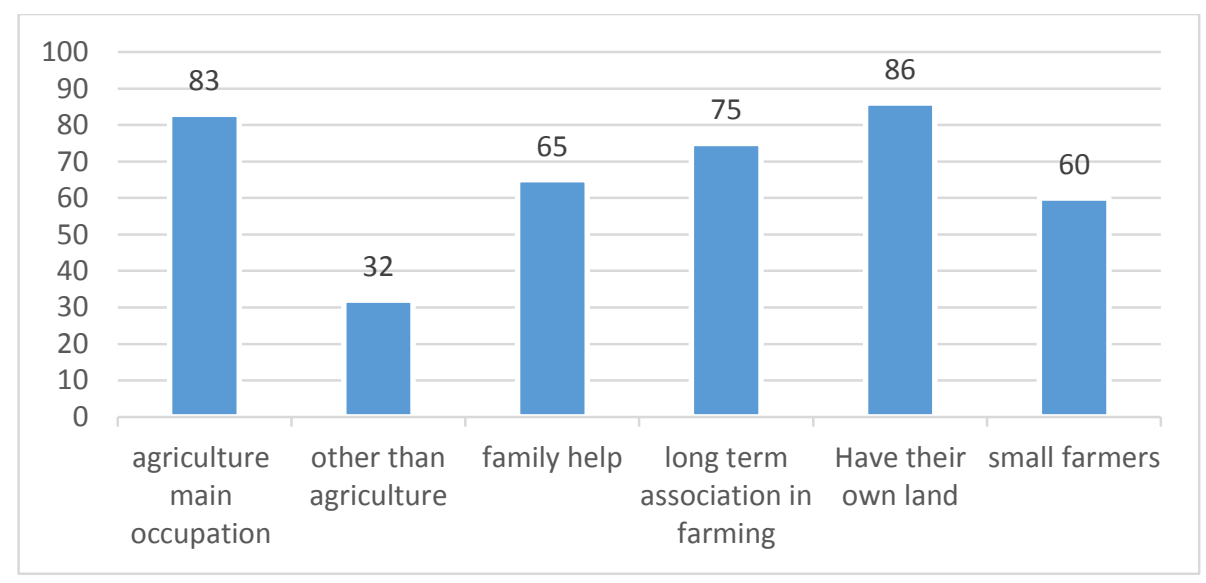

Figure 1: Socio-economic profiles of farmers

The main aspects like the seed cost, fertilizer cost, and manures that lead to plant protection have been increasing drastically, making it difficult for the farmers to invest in. This is further leading to poor quality of the crop. Inadequate water supply and an inadequate supply chain system is responsible for the present condition (Halder and Pati, 2012). The laborers who are into supporting the farmers are also diminishing because of the nuclear families migrating to the urban areas in search of employment (See Figure 2). 


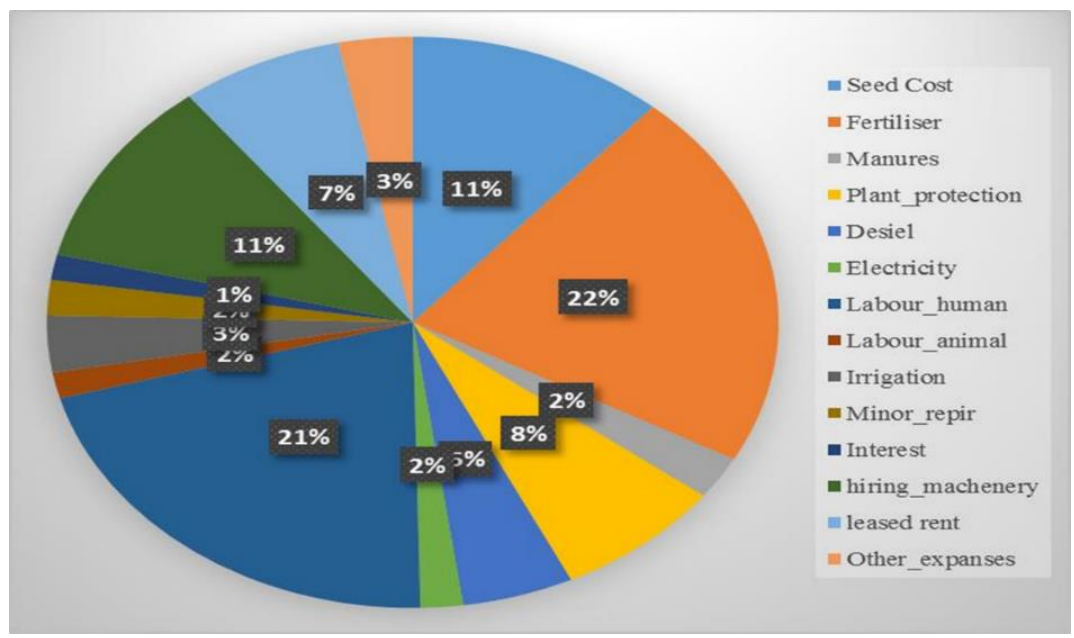

\section{Figure 2: Composition of farming expenditures}

Almost 72 percent of farmers have a great liking for farming, 22 percent did not like farming and take it because they had no other source of income, and the rest of the farmers had no other option than to choose the field of farming to make their living. Also, the crop failures and indebtedness is the main cause of loss of interest.

\section{CONCLUSION AND DISCUSSION}

To control the issues and challenges of farmers, farmers are provided with adequate support from the government authorities, through the national rural health mission. Several committees are being set up at grass root levels to address the concerns raised by the farmers. The micro-credit and microfinance policies are to be framed appropriately at regular intervals to ensure maximum support is provided to the farmers. Insurance in the fields is a major concern. This has to be in place for all kinds of crops to have optimum benefits in case of any kind of natural calamity that affects the yield. Farmers are to be provided with other benefits like the facilities of health awareness camps and other health insurance facilities. Act good for play techniques to combat the scarcity of water. The availability of the best techniques has to be ensured for a better quality of seed. Training to farmers on advancement in technology to gear up to face situations of bad yield and come up with alternate sources of income generation. Introduction of Market Intervention Schemes (MIS). This would help in attaining stability in funds. Awareness among farmers to combat international pricing strategies. India's agricultural sector has made significant progress overtime points to think over aspects that include low and volatile growth which is a serious concern. The declining average size of operational holdings. The growing disparity between agriculture and non-agriculture incomes, this is major because though the yield may increase yet the earnings of farmers may not substantially increase. The government has been taking measures to quantify this.

\footnotetext{
Funding: This study did not receive any specific financial support.

Competing Interests: The authors declared that they have no conflict of interests.

Contributors/Acknowledgement: All authors participated equally in designing and estimation of current research.

Views and opinions expressed in this study are the views and opinions of the authors, Asian Journal of Agriculture and Rural Development shall not be responsible or answerable for any loss, damage or liability, etc. caused in relation to/arising out of the use of the content.
} 


\section{References}

Ahmed, U. I., Ying, L., Bashir, M. K., Abid, M., \& Zulfiqar, F. (2017). Status and determinants of small farming households' food security and role of market access in enhancing food security in rural Pakistan. PLoS One,12(10), 1-15. http://doi.org/10.1371/journal.pone.0185466.

Arrowsmith, S. (2010). Horizontal policies in public procurement: a taxonomy. Journal of Public Procurement, 10(2), 149-186. https://doi.org/10.1108/JOPP-10-02-2010-B001.

Brammer, S., \& Walker, H. (2011). Supportable obtainment in the open division: a worldwide similar investigation. International Journal of Operations and Production Management, 31(4), 452-476.

Bundy, D. A. P. (2008). Rethinking school health a key component of education for all. The International Bank for Reconstruction and Development, The World Bank. USA.

Cohen, J. F. W., Richardson, S., Parker, E., Catalano, P. J., \& Rimm, E. B. (2014). Effect of the New U.S. branch of agriculture school meal standards on food selection, consumption, and waste. American Journal of Preventive Medicine, 46(4), 388-394.

Dhas, A. C. (2009). Agricultural crisis in India: the root cause and consequences. Munich Personal RePEc Archive. 01-14. Retrieved from https://mpra.ub.uni-muenchen.de/id/eprint/18930.

Division, B. (2007). Report of the expert group on agricultural indebtedness. Ministry of Finance. Available at: http://www.igidr.ac.in/pdf/publication/PP-059.pdf.

Dwivedi, N. (2011). Challenges faced by the agriculture sector in developing countries with special reference to India. International Journal of Rural Studies, 18(2), 2-7.

Easterling, W., P. Aggarwal, P. K., Batima, P., Brander, K. M., Erda, L., Howden, S. M., Kirilenko, A. Morton, J., Soussana, J. F., Schmidhuber, S., \& Tubiello, F. N. (2007). Food, fibre and forest products. In Climate Change 2007: Cambridge University Press, Cambridge, UK.

Gyori, M., Miranda, A. C., \& Soares, V. F. (2016). Connecting defenseless smallholder ranchers to class taking care of projects: the experience of PAA Africa. Policy in Focus, 13(2), 12-14.

Halder, P., \& Simayan, P. (2012). A need for paradigm shift to improve supply Chain management of fruits \& vegetables in India. Asian Journal of Agriculture and Rural Development, 1(1), 120.

Haroon, S., \& Sandip, P. (2014). Analyzing spatio-temporal pattern of crop diversification in Jalandhar district of Punjab, India. Asian Journal of Agriculture and Rural Development, 4(3), 242-256.

Kumar, D. S. (2016). Social Benefit Cost Analysis of Drip Irrigation. In Micro Irrigation Systems in India, Emergence, Status and Impacts. Springer Publishers, Singapore.

Manjunath, A. V., \& Ramappa, K. B. (2017). Farmers suicides- an all india study. Agro Economic Research Center, 1-108. Retrived from http://www.isec.ac.in/farmer_suicides_An\%20all\%20India\%20study09Aug2017-revised.pdf.

McCrudden, C. (2007). Purchasing social equity: Equality, government acquisition, and legitimate change. Oxford: Oxford University Press. USA

Morgan, K., \& Sonnino, V. (2008). The school food revolution: public food and the challenge of sustainable development. London: Routledge.

Niebylski, M. L., Tammy, L., Norm, R. C., Campbell, J. A., Alyssa, S., Diane, H., Karen, E. Y., Sheldon, W. T., Patrick, A. T., Mary, R. L., \& Peter, P. L. (2014). Solid nourishment obtainment arrangements and their effect. International Journal of Environmental Research and Public Health 11(3), 2608-2627.

Parida, Y., Dash, D. P., Bhardwaj, P., \& Chowdhury, J. R. (2018). Effects of drought and flood on farmer suicides in Indian states: an empirical analysis. Economics of Disasters and Climate Change, 2, 159-180. http://doi.org/10.1007/s41885-018-0023-8.

Risku, N. H., \& Loes, A. K. (2017). Natural nourishment in nourishment strategy and in broad daylight providing food: exercises gained from Finland. Organic Agriculture, 7(2), 111-124.

Sangalad, P. N. (2012). Farmers' suicides in India as a socio-economical phenomenon: a study of Karnataka state. International Journal of Criminology and Sociological Theory, 5(3), 964971. 
Shakeel, U. R., Selvaraj, M., \& Syed, I. M. (2012). Indian agricultural marketing- A review. Asian Journal of Agriculture and Rural Development, 2(1), 69-75.

Singh, A. K., \& Issac, J. (2018). Impact of climatic and non-climatic factors on sustainable livelihood security in Gujarat state of India: a statistical exploration. Agriculture and Food Sciences Research, 5(1), 30-46. http://doi.org/10.20448/journal.512.2018.51.30.46.

Smith, J. (2016). Adjusting contending strategy requests: the instance of practical open area nourishment acquisition. Journal of Cleaner Production, 112(Part 1), 249-256.

Sørensen, N. N., Tetens, I., Loje, H., \& Lassen, A. D. (2016). The effectiveness of the Danish organic action plan 2020 to increase the level of organic public procurement in Danish public kitchens. Public Health Nutrition, 19(18), 3428-3435. https://doi.org/10.1017/S1368980016001737.

Sumberg, J., \& Sabates-Wheeler, R. (2011). Connecting agricultural development to school feeding in sub-Saharan Africa: Theoretical points of view. Food Policy, 36(3), 341-349.

Talule, D. (2013). Political economy of agricultural distress and farmers suicides in Maharashtra. International Journal of Social Science and Interdisciplinary Research, 2(2), 95-124.

UNEP (2013). Reasonable public procurement: a global review. Nairobi: United Nations Environment Program. United Nations, USA.

USDA (2015). Getting local foods for child nutrition programs. Washington, DC: United States Department of Agriculture. USA.

\section{Appendix}

\section{QUESTIONNAIRE FOR FOCUS GROUP}

1. Do you know the importance of soil testing?

2. Have you done soil testing?

3. Do you know the balanced use of fertilizer ratio of NPK which is $4: 2: 1$.

4. In what ratio you use fertilizer or NPK or 1) urea, 2) complexes and DAP and 3) Potash.

5. Do you use compost or bio fertilizers?

6. Which crops do you grow?

7. What is the per acre yield of your crop.

8. Do you get the estimated profit on sales of your crop?

9. What is your suggestion for effective implementation and improvements in minimum selling price of your crops?

10. Are you happy that you are a farmer and satisfied with your agriculture output?

11. How much fertilizers do you use in one acre of land

12. Do you know that fertilizers should not be used in water logging situation

13. Do you get fertilizers as per demand and on correct price or MRP

14. Which brands of fertilizers do you prefer most

15. What is your suggestion for improvement in supply or door delivery of fertilizers

16. What kind of irrigation systems you adopt

17. Do you know the benefits of drip irrigation and incentives given by the government like subsidy on purchase of drip irrigation system

18. Have you availed subsidy on installation of drip irrigation system

19. Which are the government agencies and companies do you know providing active support in micro irrigation.

20. What is your suggestion for improvements and in installations of drip irrigation system

21. Do you have proper information of government schemes for your benefits like Shet-tal (Farm Pond) drip irrigation, farm warehouse, and vegetable processing warehouse?

22. What are your suggestion for improvements of agriculture productivity and your purchasing capacity?

Your suggestions to stop farmer's suicide and increase wellbeing of farmers. 